\title{
IODP Expeditions 304 and 305: Oceanic Core Complex Formation, Atlantis Massif
}

Scientific ocean drilling started in the early 1960s with the goal of understanding the nature of the crust-mantle boundary (the Mohorovicic discontinuity, or the Moho). This project, known as Mohole, was succeeded by the Deep Sea Drilling Project, the International Phase of Ocean Drilling, the Ocean Drilling Program, and the current Integrated Ocean Drilling Program. The major scientific goal common to all these efforts has been to recover a complete section of normal ocean crust and uppermost mantle, with the ultimate objective of understanding solid Earth cycles. This decades-old goal has not yet been fulfilled, but as geological and geophysical studies and scientific drilling have progressed over the years, we have learned a lot more about the oceanic crust. One striking discovery was that portions of slow-spreading ridges are volcanic-poor areas, classically interpreted as magmastarved regions, made of outcropping lower crust or upper mantle rocks (e.g., Cannat and Casey, 1995; Lagabrielle et al., 1998). Locally, lower crustal sections may be exposed on the seafloor by long-lived detachment faults that potentially provide a means of accessing the crust-mantle boundary. These detachment faults are exposed at the seafloor in shallow, dome-shaped features, with prominent surface corrugations trending parallel to the direction of plate spreading (e.g., Cann et al., 1997; Tucholke et al., 1998). Rocks recovered from or within a few tens of meters of the corrugated surfaces include highly deformed fault gouges and mylonites (Blackman et al., 1998; MacLeod et al., 2002; Escartin et al., 2003; Schroeder and John, 2004). The detachment faults and the corresponding series of offset tectonic blocks are referred to as oceanic core complexes (OCC), by analogy with metamorphic core complexes (e.g., Wernicke, 1981) in extensional continental terranes. The rolling hinge model (Fig. 1) of core complex formation predicts that large rotations would characterize the tectonic blocks within an OCC; as deep lithospheric rocks are exhumed along the fault, the footwall of the detachment fault (i.e., core) rolls over, laying out the geological cross section across the seafloor (Wernicke and Axen, 1988; Buck, 1988; Lavier et al., 1999).

IODP Expeditions 304 and 305 drilled on the Atlantis Massif, an OCC on the western flank of the Mid-Atlantic Ridge at $30^{\circ} \mathrm{N}$ (Fig. 2). Atlantis Massif formed since 1.5$2 \mathrm{Ma}$ at the intersection of the Mid-Atlantic Ridge and the Atlantis fracture zone. High-density mantle rocks invoked to explain observed gravity anomalies (Blackman et al., 1998, 2004) and high seismic velocities inferred from seismic refraction analysis (Collins and Detrick, 1998) were interpreted to occur less than $1 \mathrm{~km}$ below the seafloor. Crust as thin as $<1 \mathrm{~km}$ (compared to an oceanic average of 6-7 $\mathrm{km}$ ) would result from tectonic unroofing along a series of detachment faults, and this appeared to be an ideal place to reach the Moho with the currently available ocean drilling technology.

IODP Expeditions 304 and 305 had two main objectives: (1) to document the structural and lithologic properties associated with the formation of OCCs and (2) to verify the observed increase in seismic velocity at depth, determining what role seawater alteration played, and to obtain unaltered mantle peridotite from below the Moho. To accomplish these objectives, we drilled at one site in the footwall at and below the detachment fault, and at one site in the originally overlying upper crustal (basaltic) hanging wall, which is now down-dropped to the east.

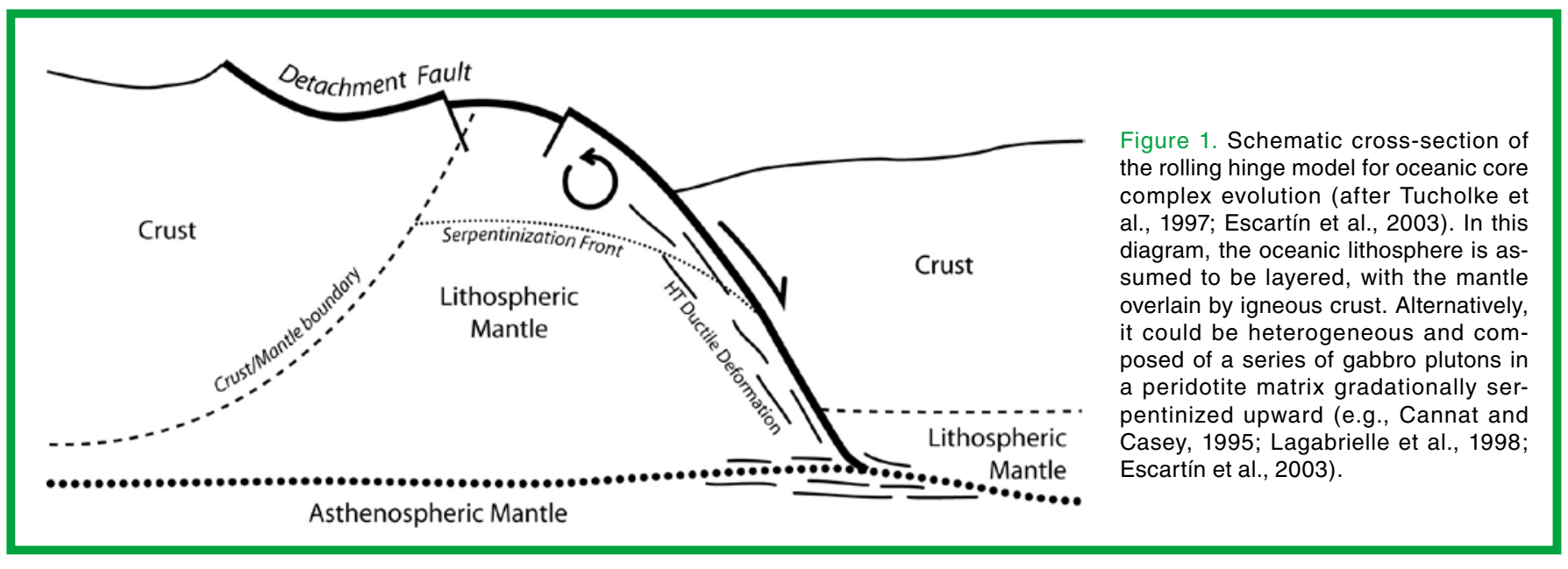


Attempts to drill the hanging wall during Expedition 304 were thwarted by difficulties associated with working in very young, fractured basalt with little sediment covering, whereas drilling at the footwall site was quite successful. A pilot hole at IODP Site U1309 (Fig. 2) on the central dome of Atlantis Massif reached just over $100 \mathrm{~m}$ depth. The main effort was at Hole U1309D, initiated during Expedition 304 and drilled to $401.3 \mathrm{mbsf}$ with an average core recovery of $64 \%$. During Expedition 305, the hole was deepened to $1415.5 \mathrm{mbsf}$ with an average core recovery of $74.8 \%$. Downhole geophysical measurements and electrical and acoustic imaging, together with the very high recovery accomplished in Hole U1309D, provided an unprecedented opportunity for core-log integration for a deep borehole in the oceanic lithosphere. Hole U1309D is the third-deepest hole in the oceanic crust, below the sediment cover, and the second-deepest hole in lower crustal and upper mantle rocks. At the end of Expedition 305, the hole was open and in good condition for future work.
The $1.4-\mathrm{km}$ sequence recovered from Hole U1309D was dominantly crustal rock types (Fig. 3), with basaltic rocks comprising $\sim 3 \%$, interlayered gabbro of highly variable grain size and modal mineralogy about $91 \%$, and ultramafics (olivine-rich troctolite and peridotite) comprising $\sim 5 \%$. The gabbroic rocks have compositions that are among the most primitive sampled along the Mid-Atlantic Ridge, as reflected in $\mathrm{Mg}$ numbers ranging from $\sim 67$ to 90 . The ultramafic rocks have distinctive textures (rounded olivines, interstitial plagioclase or clinopyroxene) and could represent the primitive end-member of the recovered mafic section. The recovery of such rocks is rare at mid-ocean ridges; in Hole U1309D the

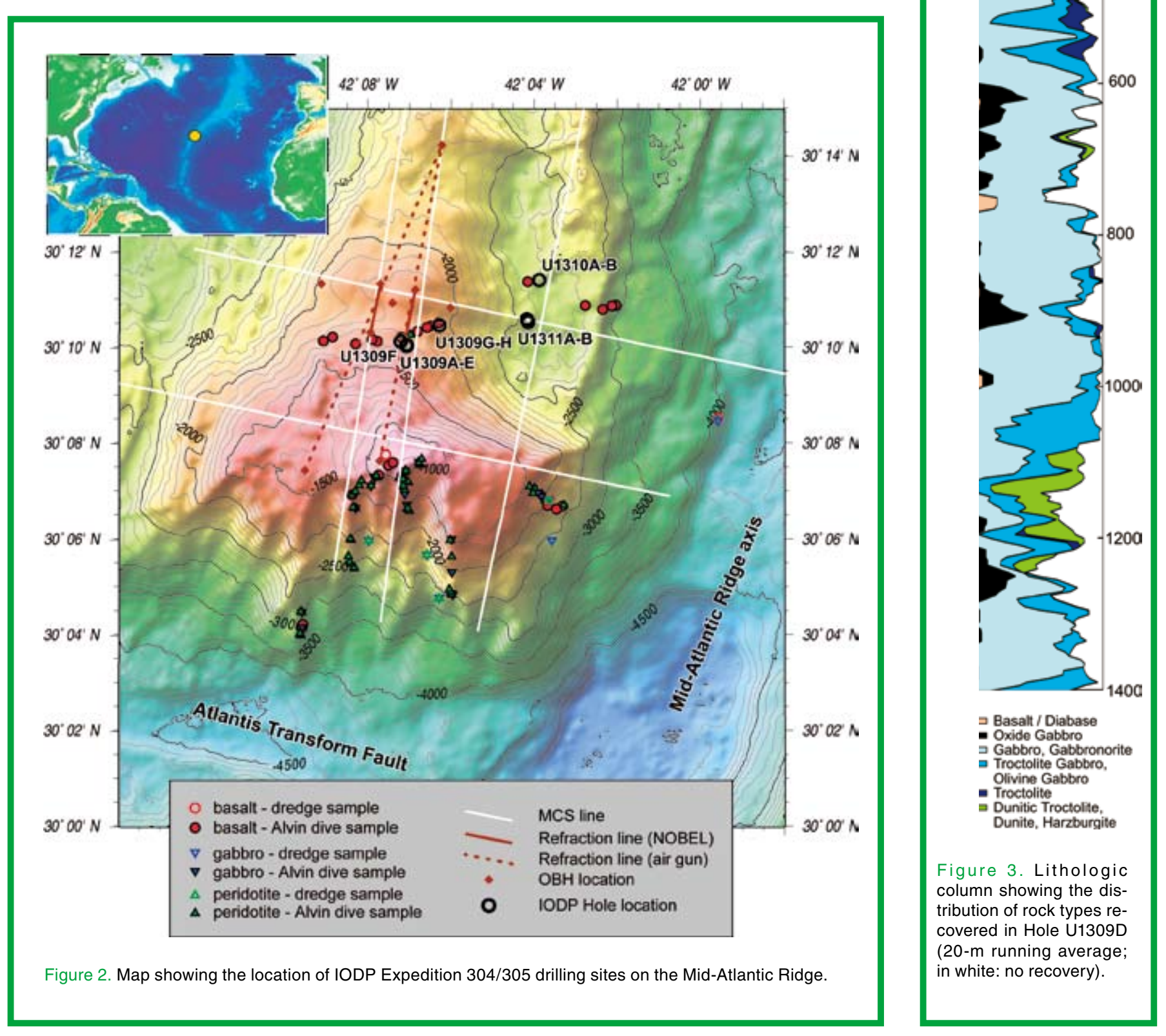


thickest ultramafic units occur between 1090 and $1240 \mathrm{mbsf}$ and most of these have undergone some hydrothermal alteration. Locally, however, some intervals are very fresh with less than $1 \%$ or $2 \%$ serpentinization, which is unique in ocean drilling records (Fig. 4).

The structural and metamorphic history recorded in Hole U1309D is separated into high- and low-temperature phases, with little deformation occurring under intermediate (amphibolite facies) conditions. Except for the very upper part of core from Hole U1309D, neither the high- nor the low-temperature deformation show preferential geometries expected for spreading-parallel detachment faulting and associated deformation. This indicates that these processes must have occurred below conditions where large-scale ductile deformation was possible and that strain was localized in very narrow zones (1-20 m thick) that may be preferentially located in the upper few tens of meters of the footwall at Site U1309. Shipboard paleomagnetic data indicate in general little deviation $\left(\leq 20^{\circ}\right)$ from the expected geocentric axial dipole orientation, especially in the upper $180 \mathrm{~m}$ of the hole; however, interpretations regarding the amount of tectonic rotation of the recovered sequence can only be speculative at this stage.

The nature of the recovered lithology, the fault orientations and unexpectedly low levels of the deformation within these rocks, and the apparent lack of anomalous paleomagnetic signature each present a paradox with respect to prior hypotheses. The dominantly mafic lithology challenges the model that OCCs form during periods of amagmatic rifting (e.g., Karson, 1990; Tucholke and Lin, 1994), as well as shows that the footwall of Atlantis Massif is not predominantly ultramafic, at least in the central dome region. The lack of extensive amphibolite facies deformation in the upper part of the core, together with the minor apparent rotation below the Curie temperature, appears difficult to reconcile with a single, deep-rooted, concave, normal fault as pictured in Fig. 1. The detachment fault capping the Atlantis Massif may have captured the gabbroic sequence recovered in Hole U1309D at a relatively shallow depth and transferred it to its present-day position with only minor tectonic rotation.

Clearly, we face a number of exciting challenges as we begin our post-cruise analyses. The existing geophysical data require further analysis, using existing but more complex processing methodologies to assess various 3-D subsurface possibilities suggested by the geologic results.

The core and logging data from Hole U1309D bring an unprecedented opportunity to understand lower crustal accretion at slow-spreading ridges. The igneous sequence represents the most primitive section of crustal rocks yet obtained in the oceans, and this is further enhanced by the fact that some sections are essentially unaltered-another first for marine igneous samples. In addition, the alteration history recorded in these rocks will allow constraints to be placed on hydrothermal and structural processes that characterized the evolution of this OCC.

\section{IODP Expedition 304 and 305 Scientists}

D. Blackman (Co-Chief Scientist), B. Ildefonse (Co-Chief Scientist), B.E. John (Co-Chief Scientist), Y. Ohara (Co-Chief Scientist), D.J. Miller (IODP Expedition Project Manager and Staff Scientist), C.J. MacLeod (Shore-based Contributor), N. Abe, M. Abratis, E.S. Andal, M. Andréani, S. Awaji, J.S. Beard, D. Brunelli, A.B. Charney, D.M. Christie, A.G. Delacour, H. Delius, M. Drouin, F. Einaudi, J. Escartin, B.R. Frost, P.B. Fryer, J.S. Gee, M. Godard, C.B. Grimes, A. Halfpenny, H.-E. Hansen, A.C. Harris, A. Tamura Hasebe, N.W. Hayman, E. Hellebrand, T. Hirose, J.G. Hirth, S. Ishimaru, K.T.M. Johnson, G.D. Karner, M. Linek, J. Maeda, O.U. Mason, A.M. McCaig, K. Michibayashi, A. Morris, T. Nakagawa, T. Nozaka, M. Rosner, R.C. Searle, G. Suhr, M. Tominaga, A. von der Handt, T. Yamasaki, and X. Zhao. 


\section{References}

Blackman, D.K., Cann, J.R., Janssen, B., and Smith, D.K., 1998. Origin of extensional core complexes: evidence from the MAR at Atlantis fracture zone. $J$. Geophys. Res., 103:21315-21334.

Blackman, D.K., Karson, J.A., Kelley, D.S., Cann, J.R., Früh-Green, G.L., Gee, J.S., Hurst, S.D., John, B.E.. Morgan, J., Nooner, S.L., Ross, D.K., Schroeder, T.J., and Williams, E.A., 2004. Geology of the Atlantis Massif (MAR $\left.30^{\circ} \mathrm{N}\right)$ : implications for the evolution of an ultramafic oceanic core complex. Mar. Geophys. Res., 23:443-469.

Buck, W.R., 1988. Flexural rotation of normal faults. Tectonics, 7:959-973.

Cann, J.R., Blackman, D.K., Smith, D.K., McAllister, E., Janssen, B., Mello, S., Avgerinos, E., Pascoe, A.R., and Escartin, J., 1997. Corrugated slip surfaces formed at ridge-transform intersections on the Mid-Atlantic Ridge. Nature (London, U.K.), 385:329 -332 .

Cannat, M., and Casey, J.F., 1995. An ultramafic lift at the Mid-Atlantic Ridge: successive stages of magmatism in serpentinized peridotites from the $15^{\circ} \mathrm{N}$ region. In Vissers, R.L.M., and Nicolas, A. (Eds.), Mantle and Lower Crust Exposed in Oceanic Ridges and Ophiolites: Dordrecht (Kluwer), 5-34.

Collins, J.A., and Detrick, R.S., 1998. Seismic structure of the Atlantis Fracture Zone megamullion, a serpentinized ultramafic massif. Eos, Trans. Am. Geophys. Union, 79(45):800. (Abstract)

Escartin, J., Mével, C., MacLeod, C.J., and McCaig, A.M., 2003. Constraints on deformation conditions and the origin of oceanic detachments: the Mid-Atlantic Ridge core complex at $15^{\circ} 45^{\prime}$ N. Geochem., Geophys., Geosyst., 4(8). doi:10.1029/2002GC000472

Karson, J.A., 1990. Seafloor spreading on the Mid-Atlantic Ridge: implications for the structure of ophiolites and oceanic lithosphere produced in slow-spreading environments. In Malpas, J., Moores, E.M., Panayiotou, A., and Xenophontos, C. (Eds.), Ophiolites: Oceanic Crustal Analogues: Proc. Symp. “Troodos 1987”: Nicosia, Cyprus (Minist. Agric. Nat. Resour.), 547-555.

Lagabrielle, Y., Bideau, D., Cannat, M., Karson, J.A., and Mével, C., 1998. Ultramafic-mafic plutonic rock suites exposed along the Mid-Atlantic Ridge $\left(10^{\circ} \mathrm{N}-30^{\circ} \mathrm{N}\right)$. Symmetrical-asymmetrical distribution and implications for seafloor spreading processes. In Buck, W.R., Delaney, P.T., Karson, J.A., and Labagrielle, Y. (Eds.), Faulting and Magmatism and Mid-Ocean Ridges. Geophys. Monogr., 106:153-176.

Lavier, L., Buck, W.R., and Poliakov, A.N.B., 1999. Self-consistent rolling-hinge model for the evolution of large-offset low-angle normal faults. Geology, 27(12):1127-1130.
MacLeod, C.J., Escartin, J., Banerji, D., Banks, G.J., Gleeson, M., Irving, D.H.B., Lilly, R.M., McCaig, A.M., Niu, Y., Allerton, S., and Smith, D.K., 2002. Direct geological evidence for oceanic detachment faulting: the Mid-Atlantic Ridge, $15^{\circ} 45^{\prime}$ N. Geology, 30(10):879-882.

Schroeder, T., and John, B.E., 2004. Strain localization on an oceanic detachment fault system, Atlantis Massif, $30^{\circ}$ N, Mid-Atlantic Ridge. Geochem., Geophys., Geosyst., 5. doi:10.1029/2004GC000728

Tucholke, B.E., and Lin, J., 1994. A geological model for structure of ridge segments in slow spreading ocean crust. J. Geophys. Res., 99(B6):11937-11958.

Tucholke, B.E., Lin, J., and Kleinrock, M.C., 1998. Megamullions and mullion structure defining oceanic metamorphic core complexes on the Mid-Atlantic Ridge. J. Geophys. Res., 103(5):9857 -9866 .

Tucholke, B.E., Stewart, W.K., and Kleinrock, M.C., 1997. Long-term denudation of ocean crust in the central North Atlantic Ocean. Geology, 25(2):171-174.

Wernicke, B., 1981. Low-angle normal faults in the basin and Range Province: nappe tectonics in an extending orogen. Nature (London, U.K.), 291:645-647.

Wernicke, B.P., and Axen, G.J., 1988. On the role of isostasy in the evolution of normal fault systems. Geology, 16:848-451.

\section{Authors}

The IODP Expeditions 304 and 305 Scientists

Contact: Benoit Ildefonse, Laboratoire de Tectonophysique, ISTEEM (CNRS-UM2), cc 49 Université Montpellier II, 34095 Montpellier cedex 05, France, e-mail: benoit@dstu.univ-montp2.fr

\section{Related Weblink}

http://iodp.tamu.edu/scienceops/expeditions/exp304.html $\mathrm{http}: / /$ iodp.tamu.edu/scienceops/expeditions/exp305.html 